\title{
Incumbents and Challengers: Conflicting Institutional Logics in SaaS ERP Business Models
}

\author{
Johan Magnusson $^{1}$, Håkan Enquist ${ }^{2}$, Gustaf Juell-Skielse ${ }^{3}$, Elin Uppström ${ }^{3}$ \\ ${ }^{1}$ Department of Business Administration, University of Gothenburg, Gothenburg, Sweden; ${ }^{2}$ Department of Applied IT, University of \\ Gothenburg, Gothenburg, Sweden; ${ }^{3}$ Center for Service Science and Innovation, Department of Computer and System Sciences, \\ Stockholm University, Stockholm, Sweden. \\ Email: Johan.Magnusson@handels.gu.se,gjs@dsv.su.se
}

Received November $14^{\text {th }}, 2011$; revised December $28^{\text {th }}, 2011$; accepted January $13^{\text {th }}, 2012$

\begin{abstract}
With a shift in the architecture for the design and delivery of information systems (IS), new business models are emerging. Professional analysts predict that by the end of 2012, a majority of all enterprise-wide information systems will be delivered by a business model dominated by services rather than by on-site installations. This paper reports on a research project conducted between 2009 and 2011 that involved case studies of Enterprise Resource Planning (ERP) systems delivered according to a Software as a Service (SaaS) logic. Using a business model ontology, 10 case studies in the Swedish ERP market were conducted and analyzed. After constructing generic business models that explain two types of vendors in the market-the Incumbents (the traditional ERP vendors) and the Challengers (the new SaaS ERP vendors) - a discussion follows, based on institutional logic, which examines how these two groups of vendors adapt the dominant institutional logic. As the results show, both vendor groups hybridize their business models using the other's institutional logic. At the same time, the vendors differentiate themselves as they try to establish the dominance of their own logic.
\end{abstract}

Keywords: Business Models; Institutional Logic; Dominant Logic; Enterprise Resource Planning; Software as a Service

\section{Introduction}

The academic community's interest in business models has generally been somewhat limited. With a few exceptions (see [1] for an overview), business models have been treated as either pre-requisites or strategies, and hence not dealt with in a theoretically sound manner [2-4]. Despite this rather narrow focus in the research, there is clear evidence that suggests business models provide a fruitful entry point for the study of value creation [5].

This paper reports on a three-year research project that investigated business models per se as well as the emerging information technology (IT) service business models. The topic of this project was Enterprise Resource Planning (ERP) vendors and their adaptation to changing technology- and business-related conditions.

The technological changes described stem from a new approach to the design, construction and delivery of software. This new approach, Software as a Service (SaaS) allows greater freedom in the packaging and sale of large systems [6-8]. Formerly, massive software packages for on-site installation and maintenance were delivered to customers. Today, customers can (in theory) construct their own IT environments by orchestrating IT services from different vendors [9], delivered on a pay-per-view basis via the Internet, without an increase in the cost of integration.

This new delivery mode for IT services results in changes to the business models traditional ERP vendors use. Where once such vendors were the sole suppliers of IT services, they now face competition from niche vendors who offer solutions that they boast the customer can easily integrate [10-12]. Because of this change, since 2008 many smaller IT service vendors have taken substantial market share from the traditional ERP vendors [13]. These niche vendors, who compete on price and time-to-deployment [14], also offer new financing terms for the costs of the ERP systems. For example, instead of promoting purchase of fully packaged software, the niche vendors may offer customers a pay-as-they-go plan or a pay-for-functionality-used plan [15].

To examine this change in the delivery of IT services, we conducted a three-year study of the rise of the new business models in order to learn how the so-called traditional ERP vendors adapt (or do not adapt) to this chal- 
lenge and how the new ERP vendors respond to the challenge. The research project was conducted as a collaborative practice research initiative [16] and involved 21 case studies of actual vendor-customer configurations.

In this paper, we use ten of these case studies to contrast and compare two types of vendors. On the one hand, we found there are traditional ERP vendors, with an installed base and products that are not delivered as SaaS, who have adapted to the changing market by developing an offering that fits the SaaS business model. We call these vendors the "Incumbents". On the other hand, we found there are new vendors who have used the SaaS business model since their entry into the market. We call these vendors the "Challengers".

In this paper, we look at business models as instances of institutional logic [17]. The concept of a dominatnt logic, which refers to the logic that the market prizes most highly, is important in this context. In relation to the design and delivery of ERP systems, we see SaaS ERP as potentially a new and dominant institutional logic.

The research question of this paper is:

How do vendors adapt their business models to a market experiencing a shift in dominant institutional logic?

To answer this question, we draw on previous research conducted on institutional theory and on business models. Using ten cases (five Imcumbent vendors and five Challenger vendors) we construct generic business models for each vendor type. We then investigate the differences between these two business models (or institutional logics) and, taking an institutional perspective, discuss the adaptation strategies the vendors use.

This paper is organized accordingly. Next, we review previous research relevant to our research question and we explain some basic assumptions underlying our paper, followed by a description of our study's method. Thereafter, in our results section, we present and compare the two generic business models. We continue with a discussion in which we take an institutional logic perspective.

\section{Previous Research and Assumptions}

\subsection{Business Models as Institutional Logic}

Various researchers [18,19-21] have studied institutional logic as the set of symbolic constructions and material practices that constitute organizing principles. In taking this approach, these researchers have tried to chart new territory related to how organizations function and how institutional change occurs.

Friedland and Alford [18: p. 248] write: "The institutional logic of capitalism is accumulation and the commodification of human activity. That of the state is rationalization and the regulation of human activity by legal and bureaucratic hierarchies. That of democracy is participation and the extension of popular control over human activity. That of the family is community and the motivation of human activity by unconditional loyalty to its members and their reproductive needs."

Thornton [22: p. 69] offers the following definition of institutional logic: “...a socially constructed, historical pattern of material practices, assumptions, values, beliefs, and rules by which individuals produce and reproduce their material subsistence, organize time and space, and provide meaning to their social reality." This definition of institutional logic closely resembles contemporary researchers' conceptualization of business models (see [1]).

Osterwalder et al. [23: p. 3] proposes yet another definition of a business model: "A business model is a conceptual tool containing a set of objects, concepts and their relationships with the objective to express the business logic of a specific firm.”

As stated above, we define business models as instances of institutional logic even though business models, by this definition, are viewed as perspectives rather than as patterns $[19,24]$. (However, we recognize there is a close similarity between these two viewpoints). In using this definition, changes in business models may be studied from an institutional logic perspective. This perspective is associated with a set of assumptions other researchers have identified.

\subsection{The Assumptions}

The first assumption is that institutional logic can be used to study change. For example, Lounsbury [25] shows that shifts in logic can be used to study change in accounting practice. In his criticism of neo-institutional theory as an overly one-sided view of isomorphism and homogenization, Lounsbury proposes the use of institutional logic and institutional rationality to understand diversity in practice. Hensman [26] and van Gestel and Hillebrand [27] have also criticized neo-institutionalism for its failure to recognize pluralism and diversity.

The second assumption is that change can be studied by focusing on both conflicting and co-existing logics. Reay and Hinings' [22] study on conflicting logics in Canadian healthcare applies institutional logic in an effort to improve our understanding of institutional change. They show that both logics are needed to explain institutional change. Thus, conflicting institutional logics can co-exist in the same field, but they need to position themselves against the dominant logic [27].

The third assumption is that institutional logics strive for domination. DiMaggio [28] uses the metaphor "battlefield" to represent the conflict between structural and dominant logics in an analysis of organizational change. In the clash between two logics, however, occasionally hybridized logics will appear. In their study of critics' reviews of a symphony orchestra, Glynn and Lounsbury 
[29] show there are definite instances where there is a blending of logics in the midst of such clashes.

These three assumptions underpin our discussion of our study's results.

\subsection{SaaS ERP as a New and Dominant Logic}

Vargo and Lusch's [30] discussion of the services dominant business logic (SD logic) focuses on intangible resources, co-creation of value, and relationships between agents. In the SD logic, people make exchanges in order to obtain specialized competences and services. In the goods dominant business logic (GD logic), people exchange goods in order to distribute goods that have added value for customers.

ERP-as-a-service is ERP delivered through a SaaS model [31]. Essentially, the model is an ERP application delivered as a service [32], accessed through a web browser [33]. In addition to business functionality, the technical infrastructure, the right to use the service, and hosting, maintenance and support are bundled as a single service [34].

ERP-as-a-service represents a shift from the GD logic in the ERP market towards SD logic [35]. As Vargo and Lusch [30] argue, the SD logic emerges as the new and dominant logic for marketing where delivery of services rather than goods is the basic principle of economic exchange. It may be argued that this is a shift in the institutional logic of marketing.

Opposed to this argument is the view that commercial software is a form of general industrial innovation. In this reasoning, SaaS ERP, as an extension of Application Service Providing (ASP), is only a temporary phase in the outsourcing market trend [36]. According to Sääksjärvi et al. [12], however, SaaS ERP models not only include ASP but also integrate valuable software into an online service infrastructure. Therefore, they argue, SaaS ERP is not a way to outsource application development but rather a radically new network process innovation. As such, SaaS should be viewed as evidence for our hypothesis that SaaS ERP is a new and dominant logic in the ERP market.

Greenwood and Hinings [37] describe a market where the possessors of power enjoy a dominant position. As their example, they use the music industry. In this market, exogenous shocks-for example, caused by new legislation or shifts in technology-are likely to have greater effect than in markets with more evenly distributed power structures (see [29] for further discussion).

The ERP market appears to be the kind of market that Greenwood and Hinings [37] describe-an oligopolistic market in which there has been significant consolidation owing to high start-up costs and the technical complexities of design that delay market entry. As a result, there are a few dominant ERP vendors who, using a M\&A strategy, acquire smaller vendors in order to reduce competiton and ensure their continued growth.

The introduction of SaaS ERP, with its limited scope and its promise of significant decreases in costs and deployment time, may cause an exogenous shock in the market. Both customers and vendors are likely to question the existing institutional logic as new vendors (the Challengers) appear who take away market share from established vendors (the Incumbents).

Hensman [26] uses the metaphor of social movement to describe a clash between institutional logics and the strategic actions that result. In this description (again, in the music industry), the existing vendors are under constant pressure from the new vendors.

Thus, a new dominant logic arises in the conflict between these two institutional logics. Momentarily, the two logics may even co-exist. It is not simply a matter of sweeping away an old logic and replacing it with a new, but rather of steadily adapting the two logics. The "battleground" metaphor is therefore apt when the introduction of SaaS ERP leads to a struggle between institutional logics.

\section{Method}

We conducted our study, the first major Swedish government-funded project on ERP and SaaS, in the years 2008 through 2011. We designed the study as collaborative practice research [16] in which we assembled representatives from 20 different actors in the SaaS ERP market. In this collaborative effort, we created 21 case studies that describe the business arrangements and strategies these actors said were important for their current business models.

We described these case studies using an expanded model of Osterwalder's [1] business model ontology. Previously, Enquist and Juell-Skielse [38,39] have made presentations of this model.

This paper reports on ten of the 21 case studies (see Table 1). As our criterion for the selection of these ten studies, we used the two extreme studies (as measured at the end points of the scale used) from our original data on the business models. We chose five traditional, wellestablished ERP vendors (the Incumbents) who had begun to deliver software according to the SaaS model. The second set of five vendors (the Challengers), who had no history of offering traditional ERP, also provided SaaS ERP.

We coded and aggregated the two sets of case studies into two generic business models using the building blocks from Osterwalder's [1] business model ontology. We then compared the models: first, by juxtaposing them against one another: second, by analysing their institutional logics in the context of the theoretical assumptions 
Table 1. The ten cases of service-oriented business models.

\begin{tabular}{ccc}
\hline $\begin{array}{c}\text { Generic Business } \\
\text { Model }\end{array}$ & Industry & Description \\
\hline Incumbent & Scrap Metal & Full ERP \\
& Manufacturing & Full ERP \\
& Accounting Services & Limited ERP \\
& Technology Consulting & Full ERP \\
& Real Estate Management & Full ERP \\
Challenger & Government & Project Management \\
& Global Transport & CRM \\
& Travel Agency & Full ERP \\
& Manufacturing & Full ERP \\
& Media Company & Full ERP \\
\hline
\end{tabular}

presented in Section 2.

\section{Analytical Model: Osterwalder's Business Model Ontology}

Osterwalder's [1] model is one of the few examples of synthesizing attempts to create an ontology for describing business models. According to this ontology, four pillars, with nine building blocks, constitute the core of a business model. See Table 2 for an overview of the ontology. This model provided the structure for the results presented in Section 4.

\section{Results}

Subsections 4.1 and 4.2 present the results from the two groups: the Incumbents and the Challengers. Subsection 4.3 refers the reader to a table summary, and Subsection 4.4 discusses the results.

\subsection{The Incumbent Service-Oriented Business Model}

The Incumbent Service-Oriented Business Model focuses on delivery of a bundle of services as a complete package. The emphasis on the model's functionality and customization is the same as that for their on-site ERP; the difference is that the model is delivered by SaaS.

The Incumbents' target customers, primarily mediumsized companies, are their traditional installed base and product customers. The Incumbents direct their marketing efforts toward the customers' chief executive officers on the assumption that it is important to establish a business relationship at the customers' highest executive level.

Interaction with customers follows the traditional ERP sales model. The first contact with customers is often made at trade fairs or in direct approaches. Thereafter, there are meetings at the customers' offices where the customers' requirements are discussed. Next there are on-site demonstrations, followed by offers and negotiations. This interaction may take a period of several weeks or months at considerable expenditure of time and money.

Value is created in the essential dialogue between the Incumbents and the customers as they work to customize (and improve) the customers' business processes. The goal of this dialogue is not to create "just another system"; rather, it is intended to affect process configuration and operations.

The Incumbents' core competences are marketing, software development and implementation methods. They rely on a partner network since, without suitable partners, the Incumbents are often too small to maintain a profitable customer base. The partner network also requires the Incumbents to select additional systems and services that are bundled with ready made and approved integrations with the ERP systems. The Incumbents' selection of SaaS, supplied by partners, largely coincides with their on-site offerings.

The Incumbents do not bundle all associated costs with their offer. Instead, they provide customers with a complete breakdown of the associated costs by categories of investment (hardware, networks and other initial costs), vendor and third-party licensing, and costs of maintaining/operating the system. The Incumbents also offer customers a dynamic pricing platform based on service levels and numbers of users. However, this platform, when applied strictly, resembles the traditional, on-site pricing model.

The revenue stream for the Incumbents is either from sales of the hardware, networks, etc. (separate from the operation costs) or from bundling everything using financing that is sometimes provided by banks or otherfinancial institutions. Incumbents often charge for consulting on a per-month basis, according to the service provided.

\subsection{Challenger Service-Oriented Business Model}

The Challenger Service-Oriented Business Model focuses on delivery of customer value to a niche market. The Challengers' interest is not in a custom market segment; rather, they target customers who are willing to accept complete standardization.

As far as value, the Challengers strive to be product leaders by delivery of a specific product. Because they want to make their products as independent as possible from other actors in the ecosystem, such as consultants, etc., they do not sell their products bundled with professional services.

Since the Challengers focus on small size companies, they direct their primary marketing efforts towards the chief information officers or their equivalents in such 
Table 2. Osterwalder's business model ontology ([1]: p. 43).

\begin{tabular}{|c|c|c|}
\hline Pillar & $\begin{array}{l}\text { Business Model Building } \\
\text { Block }\end{array}$ & Description \\
\hline Product & Value Proposition & $\begin{array}{l}\text { A Value Proposition is an overall view of a company's bundle of products and services } \\
\text { that are of value to the customer. }\end{array}$ \\
\hline \multirow{3}{*}{ Customer Interface } & Target Customer & The Target Customer is a segment of customers a company wants to offer value to. \\
\hline & Distribution Channel & A Distribution Channel is a means of getting in touch with the customer. \\
\hline & Relationship & $\begin{array}{l}\text { The Relationship describes the kind of link a company establishes between itself and } \\
\text { the customer. }\end{array}$ \\
\hline \multirow{3}{*}{$\begin{array}{l}\text { Infrastructure } \\
\text { Management }\end{array}$} & Value Configuration & $\begin{array}{l}\text { A Value Configuration describes the arrangement of activities and resources that are } \\
\text { necessary to create value for the customer. }\end{array}$ \\
\hline & Core Competency & $\begin{array}{l}\text { A Çore Competency is the ability to execute a repeatable pattern of actions that is } \\
\text { necessary in order to create value for the customer. }\end{array}$ \\
\hline & Partner Network & $\begin{array}{l}\text { A Partnership is a voluntarily initiated cooperative agreement between two or more } \\
\text { companies in order to create value for the customer. }\end{array}$ \\
\hline \multirow{2}{*}{ Financial Aspects } & Cost Structure & $\begin{array}{l}\text { The Cost Structure is the representation in money of all the means employed in the } \\
\text { business model. }\end{array}$ \\
\hline & Revenue Model & $\begin{array}{l}\text { The Revenue Model describes the way a company makes money through a variety of } \\
\text { revenue flows. }\end{array}$ \\
\hline
\end{tabular}

organizations. Their marketing is web-based and highly standardized. Delivery is rapid and remote Internet support is provided.

The Challengers use a hub in their infrastructure to integrate services delivered by external suppliers. By standardization of their offers, the Challengers keep tight control over such integration. Potential service providers are evaluated before they are included in the infrastructure. In this way, the Challengers maintain centralized control over transactional and technological matters as well as the revenues flowing from the external suppliers.

The Challengers use a system of fixed pricing for sales of their products. This is their revenue stream. The customers buy an installation and pay a flat month-user price that includes licensing, maintenance and other operation costs.

\subsection{Summary of Generic Business Models}

There are significant differences in the two generic business models for service-oriented delivery of ERP. Table 3 summarizes these differences according to Osterwalder's onotology of building blocks.

\section{Discussion}

As our results reveal, there are distinct differences between the Incumbent and the Challenger business models. The Incumbents, given their histories, can use past experience in their product and marketing strategies. The Incumbents have an installed base, established customers and an existing, complex product. In short, they have a profitable and sustainable business model behind them as they expand their product line using service-oriented architecture. The Challengers initiate a marketing stra- tegy and develop a product in a service-oriented green field. They offer a standard service to a potentially lower starting cost which attracts new market segments and challenges established vendor customer relationships.

In taking the perspective of institutional logic, new avenues of analysis are opened up. First, the new, dominant institutional logic of service orientation seems to contrast with the once dominant institutional logic of software architecture and delivery models. Although not part of this discussion, this shift in logic, which directly relates to a shift in technology, may raise the possibility of using previous research from the field of standardization.

The Incumbents relate to the change in dominant institutional logic by creating a hybrid business model. In this model, they adjust their current organizational arrangement to the market's demand for service. This adjustment requires them to move away from their traditional model in what seems to be in primarily a ritualistic [40] manner. They change the offer and their marketing strategy but maintain their developed sales process.

The Challengers also create a hybrid business model although with a different focus. With their competitive advantage gained from their core competences (development and delivery), the Challengers need not provide professional services bundled with the SaaS ERP. They resist changing their service-oriented logic to the software architecture and delivery logic. They are willing to forego the potential profits from providing professional ERP services.

The Challengers' pricing structure reflects the hybridization of their business model. In the traditional dominant institutional logic, advance payments for a certain number of licenses are required although additional users 
Table 3. Summary of challenger and incumbent generic business models for SaaS ERP.

\begin{tabular}{|c|c|c|}
\hline Business Model Building Block & Challenger & Incumbent \\
\hline Value Proposition & $\begin{array}{l}\text { Delivery of highly standardized, niched and limited } \\
\text { bundle of services sanctioned by the vendor as a } \\
\text { turn-key solution with limited scope. }\end{array}$ & $\begin{array}{l}\text { Delivery of customized bundle of services owned by } \\
\text { the vendor as complete solution. }\end{array}$ \\
\hline Target Customer & $\begin{array}{l}\text { Small to medium-sized enterprises through the CIO or } \\
\text { equivalent. }\end{array}$ & $\begin{array}{l}\text { Medium-sized enterprises through the CEO or } \\
\text { equivalent. }\end{array}$ \\
\hline Distribution Channel & $\begin{array}{l}\text { Primarily web-based, with low thresholds for testing } \\
\text { the product for free, upon registration. }\end{array}$ & $\begin{array}{l}\text { Primarily traditional ERP sales with conventions, } \\
\text { conferences and use of the existing customer-base. } \\
\text { Booking of consultant managed demos on-site. }\end{array}$ \\
\hline Relationship & $\begin{array}{l}\text { Web-based implementation and maintenance, very } \\
\text { limited direct contact with the customer. Monthly } \\
\text { billing. }\end{array}$ & $\begin{array}{l}\text { Direct contact with customer for sales and } \\
\text { implementation through own or partner network } \\
\text { associated consultants. Monthly billing. }\end{array}$ \\
\hline Value Configuration & $\begin{array}{l}\text { Value is created through the customers' adoption of the } \\
\text { product to enhance their business. }\end{array}$ & $\begin{array}{l}\text { Value is created through the adaptation of the } \\
\text { product in dialogue with the implementation } \\
\text { consultants. }\end{array}$ \\
\hline Core Competency & Software development and packaging of solutions. & $\begin{array}{l}\text { Sales, software development and implementation } \\
\text { methodology. }\end{array}$ \\
\hline Partner Network & $\begin{array}{l}\text { Limited integration with external parties within scope } \\
\text { of product. Through standardized, public APIs, the } \\
\text { product is open for third-party integration. However, } \\
\text { this service is not sold by the vendor and is not its } \\
\text { responsibility. }\end{array}$ & $\begin{array}{l}\text { Large numbers of partnerships in the form of } \\
\text { professional service-delivery (implementation and } \\
\text { maintenance) and a limited number of sanctioned } \\
\text { third-party services through direct integration in the } \\
\text { product. Full responsibility over integrations. }\end{array}$ \\
\hline Cost Structure & $\begin{array}{l}\text { Costs are displayed to the customer on a per user and } \\
\text { per month basis. }\end{array}$ & $\begin{array}{l}\text { Costs are displayed to the customer on a detailed } \\
\text { level based on investment, software (licenses), } \\
\text { hardware, consulting costs and service-level. }\end{array}$ \\
\hline Revenue Model & $\begin{array}{l}\text { Monthly payments in advance for specified number of } \\
\text { users. }\end{array}$ & $\begin{array}{l}\text { Investments are handled separately with an option } \\
\text { for the customer to allocate these costs on a } \\
\text { per-month basis. Consulting fees are billed upon } \\
\text { delivery. Monthly payments in advance for specified } \\
\text { number of users and selected service-levels. }\end{array}$ \\
\hline
\end{tabular}

may be added. Such advance billing usually involves lock-in mechanisms that set switching costs for custommers who take this option. Hence, the previous industry standard-license-associated switching costs-applies even without real technological rationality and in conflict with the core of the pricing structure of the new logic.

In this paper we have investigated two conflicting institutional logics in the ERP market where the prevailing GD logic is challenged by the emerging SD logic. These two conflicting institutional logics are reflected in two different business models, used by the vendors, namely Incumbents and Challengers. We show that these business models are hybridized, although with different focus. Can these two business models co-exist or will one of them prove to be more sustainable than the other?

In other words, is the hybrid institutional logic sustainable or is it only a passing phase towards pure SD logic? In this paper, we establish the necessary background to answer that question by contrasting and comparing the two generic business models for SaaS ERP. Future research will focus on providing an answer to this question.

\section{Acknowledgements}

The authors wish to thank Vinnova for the financial support for this research and report, and the Torsten Söderberg Foundation for the financial support for the report.

\section{REFERENCES}

[1] A. Osterwalder, "The Business Model Ontology: A Proposition in a Design Science," Ph.D.Thesis, Université de Lausanne, Lausanne, 2004.

[2] M. Porter, "Strategy and the Internet," Harvard Business Review, Vol. 79, No. 2, 2001, pp. 63-78.

[3] J. Hedman and T. Kalling, "The Business Model Concept: Theoretical Underpinnings and Empirical Illustrations," European Journal of Information Systems, Vol. 12, No. 1, 2003, pp. 49-59. doi:10.1057/palgrave.ejis.3000446

[4] S. M. Shafera, H. J. Smitha and J. C. Linderb, "The Power of Business Models," Business Horizons, Vol. 48, No. 3, 2005, pp. 199-207.

doi:10.1016/j.bushor.2004.10.014

[5] R. Amit and C. Zott, "Value Creation in E-Business," Strategic Management Journal Special Issue: Strategic 
Entrepreneurship: Entrepreneurial Strategies for Wealth Creation, Vol. 22, No. 6-7, 2001, pp. 493-520.

[6] M. A. Cusumano, "The Changing Software Business: Moving from Products to Services,” Computer, Vol. 41, No. 1, 2008, pp. 20-27. doi:10.1109/MC.2008.29

[7] M. Fan, S. Kumar and A. B. Whinston, "Short-Term and Long-Term Competition between Providers of ShrinkWrap Software and Software as a Service,” European Journal of Operational Research, Vol. 196, No. 2, 2009, pp. 661-671. doi:10.1016/j.ejor.2008.04.023

[8] M. Saeed and M. Jaffar-Ur-Rehman, "Enhancement of Software Engineering by Shifting from Software Product to Software Service," In: W. Khan and R. Ahmed, Eds., First International Conference on Information and Communication Technologies ICICT, Karachi, 27-28 August 2005, pp. 302-308.

[9] S. Abels, N. Brehm, A. Hahn and J. M. Gomez, "Change Management Issues in Federated ERP Systems: An Approach for Identifying Requirements and Possible Solutions," International Journal of Information Systems and Change Management, Vol. 1, No. 3, 2006, pp. 318-335. doi:10.1504/IJISCM.2006.011202

[10] A. Benlian, T. Hess and P. Buxmann, "Drivers of SaaSAdoption-An Empirical Study of Different Application Types," Business \& Information Systems Engineering, Vol. 1, No. 5, 2009, pp. 357-369. doi:10.1007/s12599-009-0068-x

[11] W. Torbacki, "SaaS-Direction of Technology Development in ERP/MRP Systems," International Scientific Journal, Vol. 32, No. 1, 2008, pp. 57-60.

[12] M. Sääksjärvi, A. Lassila and H. Nordström, "Evaluating the Software as a Service Business Model: From CPU Time-Sharing to Online Innovation Sharing,” In: P. Isaias, P. Kommers and M. McPherson, Eds., IADIS International Conference e-Society 2005, 27-30 June 2005, Quarwa, pp. 177-186.

[13] S. Jacobson, J. Shepherd, M. D’Aquilla and K. Carter, “The ERP Market Sizing Report 2007-2012,” AMR Research, 2008.

[14] M. Xin and N. Levina, "Software-as-a-Service Model: Elaborating Client-Side Adoption Factors,” In: R. Boland, M. Limayem and B. Pentland, Eds., Proceedings of the 29th International Conference on Information Systems, Paris, 14-17 December, 2008.

[15] V. Choudhary, "Comparison of Software Quality under Perpetual Licensing and Software as a Service,” Journal of Management Information Systems, Vol. 24, No. 2, 2007, pp. 141-165. doi:10.2753/MIS0742-1222240206

[16] L. Mathiassen, “Collaborative Practice Research,” Information Technology \& People, Vol. 15, No. 4, 2002, pp. 321-345. doi:10.1108/09593840210453115

[17] M. Lounsbury, "Institutional Rationality and Practice Variation: New Directions in the Institutional Analysis of Practice," Accounting, Organizations and Society, Vol. 33, No. 4-5, 2008, pp. 349-361. doi:10.1016/j.aos.2007.04.001

[18] R. Friedland and R. R. Alford, "Bringing Society Back In: Symbols, Practices, and Institutional Contradictions,” In:
W. W. Powell and P. J. DiMaggio, Eds., The New Institutionalism in Organizational Analysis, University of Chicago Press, Chicago, pp. 232-267

[19] W. R. Scott, M. Rueff, P. J. Mendel and C. A. Caronna, "Institutional Change and Healthcare Organization," University of Chicago Press, Chicago, 2000.

[20] R. Suddaby and R. Greenwood, "Rhetorical Strategies of Legitimacy,” Administrative Science Quarterly, Vol. 50, No. 1, 2005, pp. 35-67.

[21] T. Reay and C. R. Hinings, "Managing the Rivalry of Competing Institutional Logics,” Organization Studies, Vol. 30, No. 6, 2009, pp. 629-652.

[22] P. H. Thornton, "Markets from Culture: Institutional Logics and Organizational Decisions in Higher Education," Stanford University Press, Stanford, 2004. doi:10.1177/0170840609104803

[23] A. Osterwalder, Y. Pigneur and C. L. Tucci, "Clarifying Business Models: Origins, Present, and Future of the Concept," Communications of the Association for Information Systems, Vol. 16, No. 1, 2005, pp. 1-40.

[24] H. Mintzberg, “Crafting Strategy,” Harvard Business Review, Vol. 65, No. 4, 1987, pp. 66-75.

[25] M. Lounsbury, "Institutional Transformation and Status Mobility: The Professionalization of the Field of Finance,” Academy of Management Journal, Vol. 45, No. 1, 2002, pp. 255-266. doi:10.2307/3069295

[26] M. Hensman, "Social Movement Organizations: A Metaphor for Strategic Actors in Institutional Fields," Organization Studies, Vol. 24, No. 3, 2003, pp. 355-381. doi:10.1177/0170840603024003908

[27] N. van Gestel and B. Hillebrand, "Explaining Stability and Change: The Rise and Fall of Logics in Pluralistic Fields,” Organization Studies, Vol. 32, No. 2, 2011, pp. 231-252. doi:10.1177/0170840610397475

[28] P. J. DiMaggio, "State Expansion and Organizational Fields,” In: R. Hall and R. E. Quinn, Eds., Organization Theory and Public Policy, Sage, Beverly Hills, 1983, pp. 147-161.

[29] M. A. Glynn and M. Lounsbury, "From the Critics' Corner: Logic Blending, Discursive Change and Authenticity in a Cultural Production System,” Journal of Management Studies, Vol. 42, No. 5, 2005, pp. 1031-1055. doi:10.1111/j.1467-6486.2005.00531.x

[30] S. L. Vargo and F. R. Lusch, "Evolving to a New Dominant Logic for Marketing," The Journal of Marketing, Vol. 68, No. 1, 2004, pp. 1-17. doi:10.1509/jmkg.68.1.1.24036

[31] M. P. Papazoglou, "Service-Oriented Computing: Concepts, Characteristics and Directions," Fourth International Conference on Web Information Systems Engineering (WISE’03), Rome, 10-12 December 2003, pp. 3-12.

[32] F. Hoch, M. Kerr and A. Griffith, "Software as a Service: Strategic Backgrounder," Software and Information Industry Association, 2001. http://www.siia.net/estore/pubs/SSB-01.pdf

[33] T. Mäkilä, A. Järvi, M. Rönkkö and J. Nissilä, "How to Define Software-as-a-Service-An Empirical Study of Fin- 
nish SaaS Providers’ Software Business,” In: P. Tyrväinen, S. Jansen, M. A. Cusumano, W. Aalst, J. Mylopoulos, M. Rosemann, M. J. Shaw and C. Szyperski, Eds., Lecture Notes in Business Information Processing Springer Heidelberg, Berlin, Vol. 51, 2010, pp. 115-124.

[34] W. Sun, K. Zhang, S,-K. Chen, X. Zhang and H. Liang, "Software as a Service: An Integration Perspective," In: Service-Oriented Computing —ISOC, Vol. 4749, 2007, pp. 558-569.

[35] G. Juell-Skielse and H. Enquist, “ERP as Service,” Fifth International Conference on Research and Practical Issues of Enterprise Information Systems CONFENIS 2011, Aarhus, 16-18 October 2011.

[36] J. M. Utterback, "Mastering the Dynamics of Innovation: How Companies Can Seize Opportunities in the Face of Technological Change,” University of Illinois at UrbanaChampaign's Academy for Entrepreneurial Leadership Historical Research Reference in Entrepreneurship, 1994.
[37] R. Greenwood and C. R. Hinings, "Understanding Radical Organizational Change: Bringing Together the Old and the New Institutionalism,” The Academy of Management Review, Vol. 21, No. 4, 1996, pp. 1022-1054.

[38] H. Enquist, G. Juell-Skielse and J. Magnusson, "Service Oriented Business Models for ERP," Second Workshop on Enterprise Systems-'Affärssystem', Linköping, 21 November 2008.

[39] H. Enquist and G. Juell-Skielse, "Value Propositions in Service Oriented Business Models for ERP: Case Studies,” 13th International Conference on Business Information Systems BIS 2010, Berlin, 3-5 May 2010. Lecture Notes in Business Information Processing, Vol. 46, 2010, pp. 268-279.

[40] J. Kerr and J. W. Slocum, "Managing Corporate Culture through Reward Systems," Academy of Management Executive (08963789), Vol. 1, No. 2, 1987, pp. 99-107. 